Board of Governors of the Federal Reserve System

International Finance Discussion Papers

Number 569

October 1996

THE ROLE OF CREDIT IN POST-STABILIZATION CONSUMPTION BOOMS

Martina Copelman

NOTE: International Finance Discussion Papers are preliminary materials circulated to stimulate discussion and critical comment. References in publications to International Finance Discussion Papers (other than an acknowledgment that the writer has had access to unpublished material) should be cleared with the author or authors. 


\begin{abstract}
This paper presents an empirical investigation of the role of credit in the post-stabilization consumption booms of Mexico, Chile, and Israel. Credit from the banking sector to the private sector expanded very rapidly following the stabilizations. I show that this increase in credit reduced the proportion of consumers that were liquidity constrained in the economy. This reduction in liquidity constraints could have helped to fuel the observed consumption booms. In addition, I show that the most important channeis for the expansion in credit to consumers in Mexico are the rapid remonetization of the economy, the fall in the ratio of debt held by banks to GDP held by banks, and the increase in the foreign liabilities of banks. For Chile, the most important channel is the remonetization of the economy, whereas in Israel, it is the crowding in effect from the fall in the ratio of public debt held by banks to GDP. The fact that only the crowding in effect was important for Israel. is explained by the differences between its banking system and those of the other countries.
\end{abstract}


The Role of Credit in Post-Stabilization Consumption Booms

\author{
Martina Copelman ${ }^{1}$
}

This paper presents empirical evidence that the expansion of credit, in particular bank credit, reduces liquidity constraints of consumers after stabilizations. This reduction in liquidity constraints can help explain the consumption booms observed in Chile, Mexico, and Israel following their stabilization programs.

Conventional wisdom maintains that disinflations can have strong contractionary effects. Estimates for the "sacrifice ratio" in the U.S. lie between 3 and 18. (Sachs (1985)) ${ }^{2}$ These pessimistic evidence have usually been based on evidence from money-based stabilizations. Sargent(1982) challenges this view using evidence from the disinflation programs of the early 1920's European hyperinflations. Recently. Kiguel and Liviatan (1992) have shown that the programs in Latin America and in Israel during the mid 1980's have actually been expansionary.

The expansionary initial phase is driven by a consumption. and sometimes, an investment boom. The characteristics of these stabilizations include a large initial devaluation and a subsequent fixing of the exchange rate. Since they use the exchange rate as the nominal anchor, they are usually called exchange rate based, ERB, stabilizations. From the beginning of the program to the quarter when consumption peaked, total consumption increased by $34 \%$ in Chile, $38 \%$ in Israel, and $25 \%$ in

i The authors is staff economist in the Division of International Finance, Board of Governors of the Federal Reserve System. The views expressed in this paper are solely the responsibility of the author and should not be interpreted as reflecting those of the Board of Governors of the Federa! Reserve System or other members of its staff. I am grateful to Rudiger Dornbusch, Gustavo Canonero, Luis Herrera, Paul Krugman. Robert Solow. Alejandro Werner, and the participants of the M.I.T. International Breakfast and the Money Lunch as well as the participants of the seminars at the Federal Reserve Board for many helpful suggestions and comments.

\footnotetext{
${ }^{2}$ The sacrifice ratio is defined as the cumulative percent output loss per percentage point reduction in inflation.
} 
Mexico. ${ }^{3}$ Private consumption in Mexico increased at an average real annual rate of $5.8 \%$ during 1989-92, at 4.3\% in Chile between 1978 and 1982, and at $11 \%$ in Israel between 1985 and 1987 . Figures 1,2, and 3 show the increase in real per capita private consumption in each country.

FIGURE 1

\section{MEXICO PRIVATE CONSUMPTION}

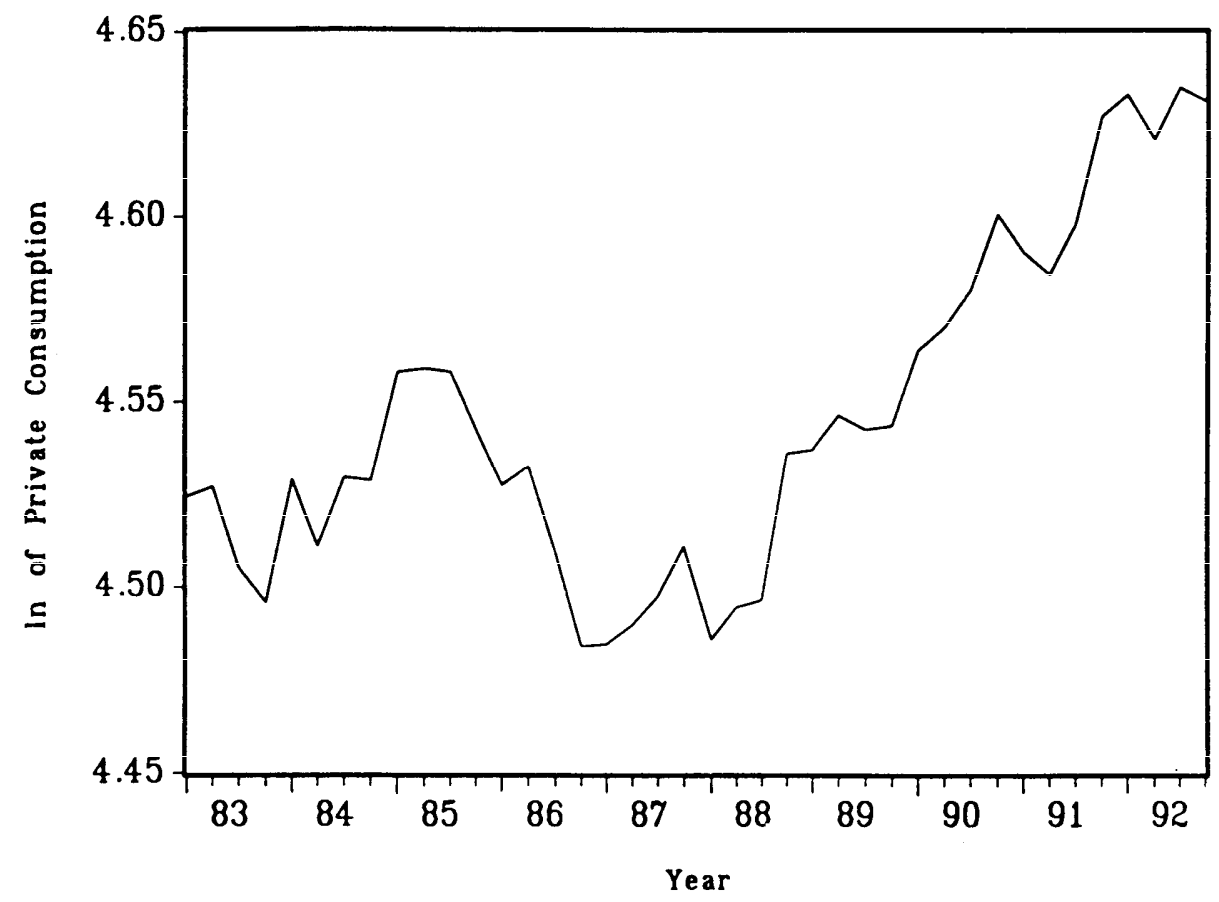

${ }^{3}$ These figures do not change much if the quarter before the stabilization is taken as the starting point. 
FIGURE 2

CHILE PRIVATE CONSUMPTION

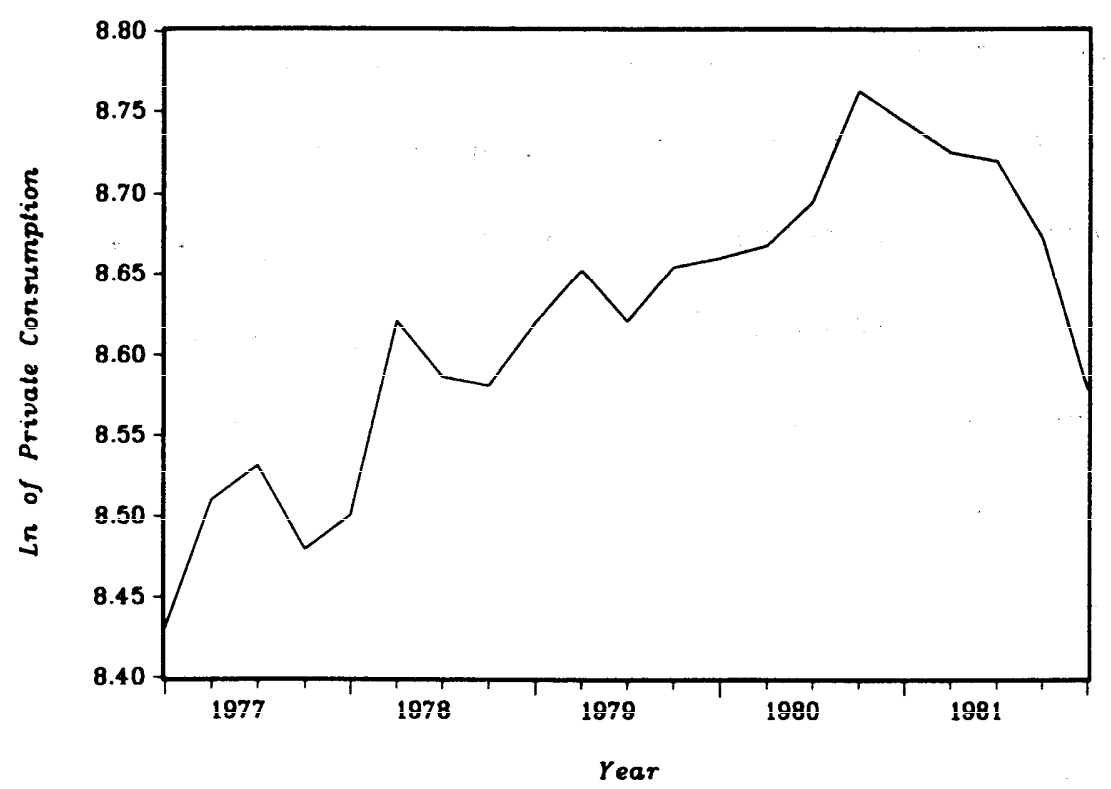

FIGURE 3

ISRAEL PRIVATE CONSUMPTION




Consumption booms following stabilizations have also been observed in Denmark in 1982 and in Ireland in 1987 by Giavazzi and Pagano (1990). The Danish experienced a consumption boom of $3.7 \%$ and an investment boom of $12.7 \%$ during 1983-1987. In Ireland, during 1987-1989, private consumption grew at an average rate of $3.6 \%$, and investment at $6.7 \%$.

Several explanations have been proposed in the literature for the mechanism through which stabilization policies could generate consumption booms. The most prominent of these is the idea introduced by Calvo (1986) that a lack of credibility in the program induces the public to increase current consumption relative to future consumption because today's effective price is lower than the post collapse price. Another idea is that the fall in the inflation rate at the beginning of the program generates a wealth effect because the value of govermment bonds (which are part of private wealth) increases. (Bruno (1992)). ${ }^{+}$This increase in the value of private wealth increases expenditure and generates a consumption boom. The third explanation, which is the focus of this paper, is that following a stabilization, credit from the banking system to the private sector increases reducing liquidity constraints in the economy. A reduction in liquidity constraints can generate a consumption boom through a decline in excess savings or lumpy purchases of consumer durables. The effects of all three of these explanations are more pronounced on consumer durables than on nondurables.

In this paper, I concentrate on two aspects of the role of credit in post-stabilization consumption booms. First, I show that there is a significant drop in the share of households that are liquidity constrained after the stabilization. Previous studies (Rossi(1988)) have shown that liquidity constraints are very important in explaining the excess sensitivity of consumption in LDC's. Deaton (1989) shows that consumers with binding borrowing constraints can have savings and asset accumulation in excess of what is optimal if those constraints were not binding. The results indicate that there was a sharp reduction in the share of liquidity constrained consumers in both Mexico and Chile, but the fall is not significant in Israel.

\footnotetext{
4 For this to hold. Ricardian non-neutrality is requitred
} 
A fall in the proportion of consumers who are liquidity constrained can generate a consumption boom in two ways. One is through a reduction in the excess savings accumulated by these households. A second is through the increase in purchases of consumer durables. All the households that prior to the stabilization were liquidity constrained and could not buy the durables they wanted can do sô when they are no longer constrained. This generates a bunching of purchases of consumer durables and a jump in total consumption expenditures. ${ }^{5}$

In the second part of the paper, I look at the three main exogenous channels through which banking sector credit expanded after the stabilizations and fuel the consumption booms by reducing liquidity constraints. Prior to the stabilizations, the combination of a small (and mostly) inefficient banking system and a high inflation environment reflected very low levels of bank credit to the private sector. particularly consumption credit. The drastic fall in the inflation rates after the stabilizations combined with progressive financial reforms worked to increase the resources available to the banking sector to finance private consumption. The ratio of banking credit to total private consumption went from 29.8 percent in 1978 to 98.4 percent in 1982 in Chile. In Mexico, the ratio of consumer credit to total private consumption went from 2.9 percent in 1987 to 10 percent in 1992 , and in Israel the ratio of unlinked bank credit to total private consumption went from $15 \%$ in 1985 to $30 \%$ in $1988 .{ }^{67}$

The results highlight the difference between the financial sectors in Mexico and Chile on the one hand, and Israel on the other. In Mexico all three channels for the increase in credit to consumers are very important; that is the remonetization of the economy, the fall in the ratio of debt held by banks to GDP, and the increase in foreign liabilities held by banks. For Chile, the most important channel is the remonetization of the economy, while for Israel it is the fall in the ratio of public sector debt held by banks to GDP. Israel's highiy indexed financial sector and its high private

\footnotetext{
${ }^{5}$ Hayashi (1982) makes a similar argument.

${ }^{6}$ In İsraei, uniinked Bank credit is the source of most consumer loans.

7 De Long and Summers (1987) also credit the increased availability of consumer loans with the reduced variability of aggregate demand and the fall in liquidity constraints in the postwar U.S.
} 
explain why there was not a significant increase in the volume of financial intermediation after the stabilization, while for Mexico and Chile this was a very important factor.

The rest of the paper is structured as follows. Section II relates the main features of the stabilization programs and the evolution of credit and consumption thereafter. Section III presents the permanent income hypothesis $(\mathrm{PIH})$ and sets out an altemative allowing for liquidity constrained consumers. The empirical investigation is carried out in Section IV and Section V concludes.

\section{A BRIEF HISTORY OF CHILE, MEXICO, AND ISRAEL}

Before turning to the estimation results, we take a brief look at the history of the three stabilization episodes.

\section{1 CHILE}

Following the coup of 1973 , the govemment of Pinochet embarked on a program that would drastically change the Chilean economy. Between 1973 and 1975, the government started an aggressive program to correct the most important distortions of the previous regime. During this period. a gradual anti-inflationary policy was implemented without much success. In April of 1975 , the first serious attempt to lower inflation was made by an orthodox program of tight money growth. By 1978. however, it had become clear that the program was not working and with inflation still running at $37 \%$ a year the govemment changed course and started targeting the exchange rate. In 1979. the government introduced a new stabilization plan by fixing the exchange rate at 39 pesos per dollar. The program worked well for a while and inflation fell to $10 \%$ by 1981 ; however, the exchange rate became progressively overvalued. By late 1981 it became apparent that the Chilean "miracle" was coming to an end. The fourth quarter of 1981 was characterized by extraordinarily high real interest rates, a huge current account deficit, rising unemployment, and a fall in real GDP. (Dombusch (1993)). The program collapsed in early 1982 and a severe financial crisis developed. During this time, real total private consumption in Chile grew at an average rate of $4.3 \%$ per year. 
As we will see later on, this consumption boom was fueled by the increase in consumer credit which relaxed liquidity constraints in the economy.

In addition to the goals of trade liberalization and inflation reduction, the stabilization plan also included measures to liberalize financial markets and ease restrictions on credit. Edwards and Cox Edwards (1991) describe Chile's financial market during most of the 60's and 70's as a textbook case of financial repression. Credit markets were underdeveloped and highly distorted; the degree of financial intermediation was extremely low, real interest rates were negative, and reserve requirements were extremely high at $100 \%$ in 1973 and then $42 \%$ in 1979 . Most importantly, credit was rationed and allocated using arbitrary and inefficient criteria. Table 1 shows the ratio of M2 to GDP, real interest rates, and credit to the private sector.

TABLE 1: CHILE: INDICATORS OF THE FINANCIAL SECTOR 1970-1981

\begin{tabular}{|c|c|c|c|}
\hline YEAR & $\begin{array}{l}\text { Real Credit to the } \\
\text { Private Sector } \\
1975=100\end{array}$ & $\begin{array}{c}\mathrm{M} 2 / \mathrm{GDP} \\
(\%)\end{array}$ & $\begin{array}{c}\text { Real Interest Rate } \\
\% \text { per year }\end{array}$ \\
\hline 1970 & 63.2 & 8.8 & \\
\hline 1971 & 91.2 & 13.1 & \\
\hline 1972 & 93.2 & 13.6 & \\
\hline 1973 & 77.2 & 10.7 & \\
\hline 1974 & 88.2 & 5.4 & \\
\hline 1975 & 100.0 & 5.6 & \\
\hline 1976 & 136.8 & 5.9 & \\
\hline 1977 & 270.0 & 8.3 & 8.8 \\
\hline 1978 & 444.3 & 10.4 & 18.9 \\
\hline 1979 & 585.0 & 12.0 & 6.8 \\
\hline 1980 & 817.2 & 13.2 & 5.9 \\
\hline 1981 & 983.7 & 21.2 & 26.5 \\
\hline
\end{tabular}

Source: Edwards and Cox Edwards (1991) and various issues of the Central Bank of Chile monthly bulletin. a) The ex-post real rates were constructed as $r=(1+i) /(1+\pi)-1$ where $i$ is the annualized nominal rate on short term deposits, and $\pi$ is the actual annualized rate of inflation. 
The numbers show a very striking increase in the volume of financial intermediation, measured by the increase in M2/GDP ratio, after 1979 . Prior to 1979 , credit to the private sector was small but increasing due to a combination of the fall in the inflation rate and some reforms to the capital markets. However, between 1977 and 1981 the real volume of total credit to the private sector increased by $264 \%$ ! Another indication of the decline in credit rationing can also be seen in the percentage fall in the spread between the deposit and the lending rate, and the increase in the credit to consumption ratio shown in Table 2 . This credit expansion led to a fall in liquidity constraints which helped to fuel the consumption boom during this period. Edwards and Cox Edwards (1991) point out that the rise in expenditure (consumption and to a lesser extent investment) was largely financed through higher credit from the banking sector.

TABLE 2: CHILE

\begin{tabular}{ccc}
\hline YEAR & $\begin{array}{c}\text { CREDIT/CONSUMPTION } \\
(\%)\end{array}$ & $\begin{array}{c}\text { SPREAD } \\
\text { \% per year }\end{array}$ \\
\hline 1975 & 6.6 & \\
1976 & 9.8 & \\
1977 & 22.7 & 38.5 \\
1978 & 29.8 & 17.3 \\
1979 & 42.7 & 12.1 \\
1980 & 59.6 & 5.5 \\
1981 & 71.3 & 10.1 \\
1982 & 100.7 & 4.6 \\
\hline
\end{tabular}

Source is various issues of the Central Bank of Chile monthly bulletin. Credit/Consumption is the ratio of total real credit to the private sector to total real private consumption. Spread is the difference between the real short term lending and deposit rate.

\section{II.2 MEXICO}

Following the debt crisis of 1982 , Mexico began a process of adjustment with the aims of reducing inflation, lower the budget deficit, and liberalize trade. In 1986. oil prices plummeted leaving Mexico with a new crisis. In response to this shock, there was a real depreciation of the peso 
which fueled inflation. By 1987, however, the acute extemal sector crisis was amplified by the severe problem of inflation, which reached almost $160 \%$ in that year. On December 15 1987, the De La Madrid administration set in motion a stabilization package called the Economic Solidarity Pact (PSE) to reduce inflation and streamline the economy. The exchange rate was fixed and used as a nominal anchor for prices.

The pact managed to reduce inflation from $159 \%$ in 1987 to $51.6 \%$ in 1988 without a recession; today inflation is around $8 \%$. In addition Mexico has been experiencing a consumption boom. Between 1989 and 1992, consumption expenditure has increased significantly and grew faster than output averaging about $5.8 \%$ per year. Table 3 shows some major economic indicators for Mexico.

TABLE 3: MEXICO: MACROECONOMIC INDICATORS

Real Rates of Growth unless otherwise stated.

\begin{tabular}{cccccc}
\hline \hline YEAR & GDP & $\begin{array}{c}\text { CONSUMER } \\
\text { PRICES }\end{array}$ & $\begin{array}{c}\text { CONS/GDP } \\
(\%)\end{array}$ & $\begin{array}{c}\text { PRIVATE } \\
\text { CONSUMPTION }\end{array}$ & $\begin{array}{c}\text { PRIVATE } \\
\text { INVESTMENT }\end{array}$ \\
\hline \hline 1986 & -3.8 & 105.7 & 63.2 & -2.6 & -11.1 \\
1987 & 1.9 & 159.2 & 62.0 & -0.01 & 6.4 \\
1988 & 1.2 & 51.7 & 62.4 & 1.8 & 10.2 \\
1989 & 3.3 & 19.7 & 64.4 & 6.8 & 7.5 \\
1990 & 4.4 & 29.9 & 65.4 & 6.1 & 13.3 \\
1991 & 3.6 & 18.8 & 66.1 & 4.6 & 12.7 \\
1992 & 2.6 & 11.9 & 68.2 & 5.9 & 20.4 \\
\hline \hline
\end{tabular}

This consumption boom has been fueled by the extraordinary increase in the volume of financial intermediation and real consumer credit which has significantly reduced the proportion of the population that is liquidity constrained.

Prior to 1988, the financial sector of Mexico was severely underdeveloped and repressed. Quantitative restrictions to credit were widespread, and interest rates were highly regulated. Between 
the 1950 's and 1980 's, control over credit was exercised through the quantitative controls on the intemediaries by the imposition of very high reserve requirements, selective credit quotas, and borrowing interest rates set by the Banco de Mexico-in many cases upon instructions from the ministry of Finance- and not by current market conditions. (Aspe (1993)).

Thorough financial reforms were implemented along with the new pact. Starting in the fall of 1988 , interest rates were allowed to vary more due to market conditions, and "credit quotas" to high priority sectors were eliminated. By 1989 , the selective credit mechanism was no longer in place, compulsory reserve requirements were removed, and new financial instruments were created. Aili these reforms were further strengthened by the full privatization of the banking system which began in M̃ay 1990 and was completed in 1992.

The combined effect of the exchange rate based stabilization and the financial reforms was to increase the amount of consumption credit to the private sector, through the increase in the volume of financial intemediation. Tables 4 and 5 show the rapid increase in credit and the volume of financial intemediation (as measured by M2/GDP and M4/GDP).

TABLE 4: MEXICO: FINANCIAL INTERMEDIATION MEASURES

\begin{tabular}{llll}
\hline \hline YEAR & $\begin{array}{l}\text { M2/GDP } \\
(\%)\end{array}$ & $\begin{array}{l}\text { M4/GDP } \\
(\%)\end{array}$ & $\begin{array}{l}\text { Financing to Pvt. Sector } \\
(\% \text { of GDP) }\end{array}$ \\
\hline \hline 1985 & 27.7 & 33.3 & 12 \\
1986 & 32.2 & 41.2 & 11 \\
1987 & 31.8 & 43.7 & 10 \\
1988 & 22.4 & 34.4 & 10.5 \\
1989 & 24.6 & 39.9 & 14.5 \\
1990 & 26.6 & 43.2 & 18.0 \\
1991 & 31.1 & 44.8 & 26.0 \\
1992 & 31.9 & 45.8 & 33.0 \\
\hline \hline
\end{tabular}


TABLE 5: MEXICO CREDIT GIVEN TO INDIVIDUALS BY COMMERCIAL BANKS

Real Rate of Growth

\begin{tabular}{lll}
\hline \hline & $90-91$ & $91-92$ \\
\hline \hline Total to firms and individuals & 41.1 & 36.8 \\
Total to individuals & 59.0 & 55.9 \\
Credit to Indiv. by Type & & \\
Consumption & 67.5 & 49.9 \\
Credit Cards & 51.6 & 30.1 \\
Durable Goods & 100.5 & 129.8 \\
Housing & 52.6 & 60.9 \\
\hline
\end{tabular}

Note: Sources for both table 4 and 5 are the Annual Report of the Banco de Mexico 1992 and The Mexican Economy 1993 from the Banco de Mexico. Data for Tabie 5 does not include financing from non-banking financial intermediaries.

As these Tables clearly indicate, the growth in real credit has been spectacular, particularly credit for consumption, durable goods, and housing. Credit to private individuals more than doubled in 1991 and 1992. We will see in the next section how this increase in credit led to a fall in liquidity constraints which fueled the consumption boom.

\section{II.3 ISRAEL}

Following the stock market collapse of 1983 , a balance of payments crisis developed in Israel. A maxi-devaluation led to a step increase in the inflation rate. After several tries with three "package deals" among the government, the major union organization (the Histadrut), and the association of private employees to lower inflation through wage and price freezes, the government introduced an exchange rate based stabilization program in July of 1985 . The main objectives of the plan were to reduce inflation and improve the balance of payments.

The program that was announced was very tough: it planned to reduce the budget deficit by at least $5 \%$ of GNP. This was achieved mostly through sharp cuts in subsidies and higher taxes. The sheqel was initiailly devalued by $19 \%$ and then fixed at 1.5 sheqel per dollar for a time. Wages and prices were allowed a one-time adjustment and then frozen at levels that caused a significant reduction 
in the real wage in the initial months of the program. (Bruno et al..(1991)).

The plan was extremely successful in reducing both inflation and the budget deficit.

Infiation fell from $500 \%$ a year to approximately $16-20 \%$ per year over the next couple of years, and the government deficit fell from an average of $15 \%$ of GNP in the previous decade to being balanced and even a slight surplus in 1986. The success of the program was reflected in a rapid consumption boom. Between 1986 and 1987 total private consumption grew at an average annual rate of over $11 \%$. This boom eventually deflated in late 1988 as a recession set in. Table 6 shows some main economic indicators for this period.

TABLE 6: ISRAEL MAIN ECONOMIC INDICATORS

Real Rate of Growth per year (\%)

\begin{tabular}{cccc}
\hline \hline YEAR & GDP & Private Consumption & $\begin{array}{c}\text { Gross Domestic } \\
\text { Investment }\end{array}$ \\
\hline \hline $81-85$ avg & 2.9 & 4.4 & 0.1 \\
85 & 3.9 & 0.5 & -10.6 \\
86 & 3.6 & 14.2 & 10.4 \\
87 & 5.2 & 8.5 & 2.9 \\
88 & 1.6 & 3.8 & -1.9 \\
89 & 1.3 & 0.0 & -2.7 \\
90 & 5.4 & 5.3 & 22.6 \\
\hline \hline
\end{tabular}

Source: Bank of Israel Annual Report various issues.

The consumption boom was partly fueled by the increase in real credit from the banking sector to the private sector. Between 1985 and 1990 the credit to consumption ratio doubled. See Table 7. However, unlike the Mexican or the Chilean case, Israel's financial system is highly indexed. A very large proportion of the financial system are liquid assets, mainly foreign currency denominated accounts, which are linked to the exchange rate or the CPI. In addition, about half of the credit given to the private sector by banks is indexed credit. The indexation of the financial system acts to protect depositors from inflation and devaluation risk. This means that Israeli's were able to obtain credit prior to the stabilization as well as after it. 
TABLE 7 ISRAEL: INDICATORS OF THE FINANCIAL SECTOR

\begin{tabular}{ccccc}
\hline \hline YEAR & $\begin{array}{c}\text { Credit/ } \\
\text { Consumption } \\
(\%)\end{array}$ & $\begin{array}{c}\text { M3/GNP } \\
(\%)\end{array}$ & $\begin{array}{c}\text { Real credit to the Private } \\
\text { Sector }\end{array}$ & $\begin{array}{c}\text { Real Interest Rate }^{\mathrm{a}} \\
\text { \% per year }\end{array}$ \\
\hline \hline 85 & 15.2 & 32.2 & 0 & 26.4 \\
86 & 22.8 & 31.1 & 48.3 & 17.5 \\
87 & 25.2 & 31.2 & 62.2 & 26.2 \\
88 & 30.3 & 29.0 & 32.1 & 18.9 \\
89 & 32.5 & 27.3 & 17.8 & 10.0 \\
90 & 34.09 & 26.5 & 26.3 & 4.4 \\
\hline
\end{tabular}

Source: Various issues of the Annual Report of the Bank of Israel.

(a)On uniinked free credit. (b)From Commercial Banks

One of the main regulations introduced with the stabilization program prohibited any new (foreign currency indexed) resident deposits with maturities of less than a year (PATAM). The disinflation along with the new regulation on foreign currency deposits was reflected as an increase in the relative demand for unindexed short-term assets, whose share in total private assets quadrupled during the period 1984-1987. See Table 8 . This reshuffling of the public's asset portfolio from foreign currency deposits (included in M3) to short term sheqel deposits (which are in M2) meant that in Israel there was not a marked increase in the volume of financial intermediation like in Mexico or Chile. Table 7 shows that the ratio of M3 to GNP remained relatively constant throughout the period. 
TABLE 8 ISRAEL: ASSETS OF THE PRIVATE SECTOR

Percent of Total Assets

\begin{tabular}{cccc}
\hline YEAR & \multicolumn{2}{c}{ INDEXED } & UNINDEXED \\
& $\begin{array}{c}\text { Savings \& Long Term } \\
\text { Deposits }\end{array}$ & $\begin{array}{c}\text { Resident Deposits }{ }^{\mathrm{a}} \\
\text { Demand Deposits }{ }^{\mathrm{b}}\end{array}$ & \\
\hline \hline 85 & 36.7 & 32.1 & 22.4 \\
86 & 37.5 & 26.5 & 28.7 \\
87 & 38.9 & 24.5 & 28.5 \\
88 & 59.9 & 27.0 & 31.5 \\
89 & 43.2 & 22.4 & 31.1 \\
\hline \hline
\end{tabular}

Note: Source is the Annual Report of the Bank of Israel. various issues

(a) includes Patams and other resident deposits (b) Includes currency in circulation

As we see, Israel is a case which is different from the other two countries. First, the consumption boom was only short lived (between 1986 and 1987) after which a recession ensued. See Table 6. Second, the role of credit in this expansion is not as marked in the data since due to the indexed nature of the financial system Israelis were able to keep their money at home and therefore were able to get loans prior to the stabilization. Finally, the process of liberalizing the financial sector began very late and did not bear on the supply of consumer credit. The first minor changes were not done until 1987 and more was done in 1990. These effects will become evident in the empirical results presented below.

Next, we set up the model of the PIH with an allowance for liquidity constrained consumers to see if the share of consumers which are liquidity constrained falls in these countries following the stabilizations.

\section{THE PERMANENT INCOME HYPOTHESIS AND LIQUIDITY CONSTRAINTS}

In this section we present the permanent income hypothesis (PIH) when we allow for the presence of liquidity constraints. This model will allow me to test whether liquidity constraints actually fall after the stabilizations. 


\section{III.1. The Theory}

Following Hall(1978), the PIH can be modeled from the decisions of a representative consumer. The basic set of assumptions are that consumers i) can freely borrow and lend at the same rate of interest ii) have rational expectations iii) have identical-time separable preferences with either a quadratic or logarithmic instantaneous utility function and iv) cannot die in debt. The representative consumer maximizes

$$
\begin{aligned}
& V\left(A_{t}\right)=E_{t} \sum_{t=t}^{\prime}(1+\delta)^{-1} U\left(C_{t}\right) \quad U^{\prime}>0 \quad U^{\prime \prime}<0 \\
& \text { s.t. (1) } A_{t+1}=(1+r)\left(A_{t}+w_{t}-C_{t}\right) \quad \text { for } t=1, \ldots, T-1
\end{aligned}
$$

(2) $\quad A_{q} \geq 0$

where $\mathrm{T}$ is the length of time a person lives, $\mathrm{C}$ is consumption, $\delta$ is the subjective rate of discount, $\mathrm{w}_{\mathrm{t}}$ is labor income, $A_{t}$ are asset holdings, $r$ is the constant rate of return on assets, and $E_{t}$ is the expectation conditional on the information available at time $t$.

The first order condition necessary for an optimum is

$$
E_{,} U^{\prime}\left(C_{i+1}\right)=\left(\frac{1+\delta}{1+r}\right) U^{\prime}\left(C_{i}\right)
$$

This is the Euler equation which is usually tested in consumption models; it says that marginal utility today is the best forecast of marginal utility tomorrow up to a constant multiple.

If we assume $r=\delta$ and that $U\left(C_{t}\right)$ is quadratic, ${ }^{8}$ then marginal utility is linear and we can use the random walk result for consumption which states that $E_{t}\left(C_{t+1}\right)=C_{t}$. This says that consumption today is the optimal forecast of consumption tomorrow, which implies

$$
\Delta C_{1}=\varepsilon_{1}
$$

\footnotetext{
${ }^{8}$ For example. the typical quadratic utility function is $U\left(C_{t}\right)=-\left(\alpha-C_{t}\right)^{2}$. The results hold if $U\left(C_{1}\right)$ is close to quadratic or the change in marginal utility from one period to the next is small.
} 
where $\varepsilon_{t}$ is a rational forecast error and represents the news in permanent income. So, the change in consumption is not forecastable; that is no information in $t-1$ or before can help in predicting future consumption growth.

In empirical tests of the PIH, however, Flavin (1981) and Hayashi (1982) have found that certain variables (e.g current disposable income, stock prices etc..) have enough predictive power to reject the random walk hypothesis. ${ }^{9}$ This excess sensitivity of consumption to anticipated changes in income suggests an alternative hypothesis.

Following Campbell and Mankiw (1989), I nest the PIH in a more general model which allows for some liquidity constrained consumers. In this model, there is some fraction $\lambda$ of income which accrues to individuals who consume their current income (i.e. they are liquidity constrained), while the remainder $(1-\lambda)$ accrues to individuals who consume their permanent income.

Total income then, is the sum of the two groups' respective income; that is $Y_{t}=Y_{1 t}+Y_{2 t}$. Where $Y_{11}$ is the income of the liquidity constrained consumers, and $Y_{21}$ is the income of the group which behaves according to the PIH. Since the first group receives $\lambda$ of total income, $Y_{1 t}=\lambda Y_{1}$ and $Y_{2 t}=(1-\lambda) Y_{1}$. Per capita consumption in the first group is then $C_{1 t}=Y_{1 t}=\lambda Y_{1}$, implying that

$$
\begin{aligned}
& \Delta C_{11}=\Delta Y_{11}=\lambda \Delta Y_{1} \\
& \Delta C_{2 t}=(1-\lambda) \varepsilon_{1}
\end{aligned}
$$

Using equation (4) the change in total per capita consumption can be written as

$$
\Delta C_{1}=\Delta C_{11}+\Delta C_{2 t}=\lambda \Delta Y_{1}+(1-\lambda) \varepsilon_{1}
$$

Under this alternative hypothesis, the change in consumption is a weighted average of the change in current income and the unforecastabie innovation in permanent income. Equation (5) reduces to the Hall(1978) PIH when $\lambda=0$.

\footnotetext{
${ }^{9}$ For other studies were excess sensitivity has been found see Hansen and Singleton (1982).
} 


\section{III.2 Consumption and the Real Interest Rate}

The "random walk" hypothesis for consumption depends on the assumption that the real interest rate is constant. However, the countries in our sample all experienced large changes in the real interest rate. If we ignore this effect, variation of the real interest rate can make consumption appear excessively sensitive to income even though individuals intertemporally optimize without any borrowing constraints. 10 /

The generalization of the consumer's Euler equation to allow for changes in the real interest rate (in log linear form) is $\underline{11}$

$$
\Delta C_{1}=\mu+\lambda \Delta Y_{1}+\theta r_{1}+\varepsilon_{1}
$$

where $r_{t}$ is the real interest rate contemporaneous with $\Delta C_{t}$, and $\varepsilon_{t}$ may be correlated with $r_{t}$, but is uncorrelated with lagged variables. The coefficient $\theta=(1-\lambda) \sigma$ where $\sigma$ is the intertemporal elasticity of substitution. Equation (6) tells us that high ex ante real interest rates should be associated with rapid growth of consumption.

\section{LIQUIDITY CONSTRAINTS, CREDIT EXPANSIONS, AND STABILIZATIONS}

In this section, we use the framework developed in the previous section to investigate the effects of credit expansions after stabilizations on liquidity constraints. First, I look at whether there was a reduction in liquidity constraints after the stabilizations, then I examine if there is a positive correlation between increases in credit to the private sector and private consumption. Finally, I look at the channels through which credit expansions occurred in Mexico, Israel, and Chile.

10/ See Christiano (1987) on this point.

11 See, for example. Hansen and Singleton(1982), and Hall(1988). Note that in the process of log-linearizing the first-order condition. the variance of consumption growth has been included in the constant term. Hence, heteroskedasticity is one possible reason for rejection of the model; see Barsky(1985) for a preliminary exploration of this issue. 


\section{IV.1 Stabilizations and Liquidity Constraints}

Using the model set up in section III, we estimate $\lambda$ directly and test the hypothesis that $\lambda=0$ against the alternative that consumers are liquidity constrained $(1<\lambda<0)$. This direct estimation of $\lambda$ has the advantage of providing a useful measure of the economic importance of deviations from the theory. For example, if the estimate of $\lambda$ is close to zero then one can say that the PIH is approximately true even if $\lambda$ is statistically significant.

Since the error term may be correlated with $\Delta Y_{1}$, we use instrumental variables, because least squares estimation of equation (6) can produce inconsistent estimates. Any lagged stationary variables are potentially valid instruments since they are orthogonal to $\varepsilon_{\mathrm{t}}$. The instruments used were selected because they help predict income growth. The instruments I used are a combination of the following; lags two through four of each of the following variables, $\Delta C_{t}, \Delta Y_{t}$, and the following per capita variables real exports, real government expenditure, real government consumption, real investment, real $\mathrm{Ml}$, the terms of trade and a trend. 121

I estimated equation (6) for Mexico, Chile, and Israel under the null hypothesis that $\lambda$ remained constant during the entire sample period. The alternative hypothesis is that $\lambda$ fell after the stabilization program. The model is a log-linear approximation to the true model in levels and differences since aggregate time series on consumption and income seem to be closer to log-linear than linear. That is, the mean change and the innovation variance both grow with the level of the series.13/

Due to the fact that consumption and income are measured as quarterly averages rather than points in time, then measured consumption is the time average of a random walk if the permanent income hypothesis holds in continuous time. Therefore, the change in consumption will have a firstorder serial correlation of 0.25 , which could lead us to reject the model even if it is true. To

121 Several combinations of these instruments were tried for each country, the results did not vary much from the ones ieporited hễê.

13/ See Campbell and Deaton (1989) on this. 
eliminate this problem, the instruments I used are lagged more than one period, so there is at least a two-period time gap between the instruments and the variables in equation (6). The time average of a continuous time random walk is uncorrelated with all variables lagged more than one period, so by using twice-lagged instruments we obtain a test of the model that is valid for time-averaged data.14/

To estimate the model I used data from various sources including the IFS and data provided by the Central Banks of Mexico, Chile, and Israel.15/ The data used are as follows: $Y_{t}$ is per capita real GDP. $C_{t}$ is total real private consumption per capita and $r_{t}$ is the real interest rate which was constructed from the nominal ex post deposit rate for Mexico and Chile, and from the lending rate in İsrael.16/

There are two data issues to deal with here. The first, is that for the countries studied here, relatively long time series of quarterly consumption data are only available for total private spending which includes durables.17/ If we assume exponential depreciation, however, durability should merely lead to the change in consumer spending being a first-order moving average process rather than white noise.18/ Since I am using twice-lagged instruments, the inclusion of spending on durables does not change the implication of the permanent income hypothesis that forecastable changes in income should not lead to forecastable changes in consumption. Second, I use GDP as a proxy for disposable personal income. This is not a perfect proxy but it should still provide a valid test of the null hypothesis that the permanent income theory is correct.

14/ See Working (1960) on this.

15' İ would like to thank Gil Bufman, Leonardo Leiderman, Rafí Melnick. Carmen Reinhart, Rodrigo Vergara, and Martin Werner for providing me the data used in this paper. For Israel and Mexico $\mathrm{C}$ and $\mathrm{Y}$ are seasonally adjusted.

16/ The ex-post real interest rate was calculated as $\mathrm{r}=[(1+i) /(1+\pi)]-1$. Where $\mathrm{i}$ is the annuaized deposit or lending rate, and $\pi$ is the annualized quarterly inflation rate.

17) Hayashi(1982) makes the point that a measure of consumption which includes expenditures on durables is a more relevant measure of consumption for liquidity constrained consumers since they must use their saved income to purchase durables.

18/ See Mankiw (1981) on this. 
The final equation estimated for each country consisted of:

$$
\Delta C_{t}=\mu_{0}+\lambda_{0} \Delta Y_{t}+\theta_{0} r_{t}+\mu_{1} D_{t}+\lambda_{1} D Y_{t}+\theta_{1} D r_{t}+\varepsilon_{t}
$$

where $D_{t}$ is a dummy variable equal to 0 prior to the stabilization and 1 afterwards, $D Y_{t}=\Delta Y_{t} * D_{t}$, and $\mathrm{Dr}_{\mathrm{t}}=\mathrm{r}^{*} \mathrm{D}_{\mathrm{t}}$.

The dummy variables are defined as follows.

1) Mexico $D=0 \quad 1980.1-1987.4$

$$
1 \quad 1988.1-1992.4
$$

2) Chile $D=0$ 1975.1-1978.4

$$
1 \text { 1979.1-1983.1 }
$$

3) Israel $D=0 \quad 1980.1-1985.4$

$$
1986.1-1992.4
$$

Table 9 shows the results.

TABLE 9: $\Delta C_{t}=\mu_{0}+\lambda_{0} \Delta Y_{t}+\theta_{0} r_{t}+\mu_{1} D_{t}+\lambda_{1} D Y_{t}+\theta_{1} D r_{t}+\varepsilon_{t}$

\begin{tabular}{cccc}
\hline \hline TSLS Estimates & MEXICO & CHILE & ISRAEL \\
& $1980.1-1992.4$ & $1975.1-1983.1$ & $1980.1-1992.4$ \\
\hline \hline 1. $\mu_{0}$ & $0.0039(.99)$ & $-0.001(-0.02)$ & $0.004(.45)$ \\
2. $\lambda_{0}$ & $0.931(4.6)^{\mathrm{a}}$ & $0.863(1.72)^{\mathrm{c}}$ & $0.88(2.19)^{\mathrm{b}}$ \\
3. $\theta_{0}$ & $0.042(1.8)^{\mathrm{c}}$ & $-0.03(-0.24)$ & $0.003(.31)$ \\
4. $\mu_{1}$ & $0.005(.97)$ & $-0.043(-0.7)$ & $-0.003(-.21)$ \\
5. $\lambda_{1}$ & $-0.783(-2.63)^{\mathrm{a}}$ & $-0.70(-1.00)$ & $-0.88(-1.49)^{\mathrm{d}}$ \\
6. $\theta_{1}$ & $-0.086(-2.56)^{\mathrm{a}}$ & $-0.25(-0.92)$ & $0.04(1.04)$ \\
7. $\mathrm{N}$ & 47 & 32 & 48 \\
8. $\Delta \mathrm{Y}_{\mathrm{t}} \mathrm{R}^{2}$ & .09 & .49 & .0002 \\
9. $\Delta \mathrm{r}_{\mathrm{t}} \mathrm{R}^{2}$ & .79 & .93 & .51 \\
F-Statistic & 6.94 & 1.00 & 2.21 \\
Critical $\mathrm{F}(10 \%)$ & 2.84 & 2.88 & 2.84 \\
\hline \hline
\end{tabular}

Note: t-statistics are presented in parentheses. (a) indicates significant at the 1\% level, (b) at the 5\% level, and (c) at the $10 \%$ level (d) at the $15 \%$ level. The F-Statistics were calculated using the corrected method suggested by Wooldridge (1991). Different combinations of the instruments gave very similar results. 
The estimates for the proportion of the population that is liquidity constrained clearly show a decrease after the stabilizations. For Mexico, the estimate is 0.93 before the stabilization and 0.15 after, with the drop significant at the $1 \%$ level. For Chile, the estimate is 0.86 before, and 0.16 after. Finally, for Israel the estimate is 0.88 before and 0.0 after at the $15 \%$ level. An F-test shows that the change in $\lambda$ for Mexico is significant at the $5 \%$ level, for Chile is significant at the $25 \%$ level, and for Israel it is significant at the $15 \%$ level. Even though for both Chile and Israel the drop in $\lambda$ is not significant at normal levels, this is partly due to the small number of data points before the stabilization and in the case of Chile after the stabilization as well. For Chile, when the sample is extended to 1989 the magnitude of the coefficients do not change but the drop in $\lambda$ becomes significant at the $5 \%$ level. Rows 8 and 9 present the first stage adjusted $\mathrm{R}^{2}$, which are high relative to those found by Campbell and Mankiw (1989), indicating that the instruments used have significant power in predicting income growth and the interest rate. This implies that we can reject the permanent income hypothesis and the hypothesis that $\lambda$ remained constant throughout the sample with a fair bit of confidence.

The results of Table 9 show that liquidity constraints fell drastically after the stabilizations, in the next section we determine that this was brought about by an increase in credit from the banking sector

\section{IV.2 Consumption and Credit}

If in fact the expansion of credit reduces liquidity constraints and can therefore be used as an explanation for the consumption booms we observe, then the model presented in section III is an approximation. In particular, in a complete model of consumption with borrowing constraints the fraction of consumers exhibiting excess sensitivity $(\lambda)$ will depend on a variety of factors such as wealth, income, individual characteristics, and more importantly, on how well credit markets function. 
Table 10 presents the sample correlations between total per capita private consumption and credit to the private sector from the banking system. This correlation gives us an index by which to measure how consumption and credit move together. The correlation between the two series is strongest for Mexico, but for all three countries it is fairly strong.

TABLE 10: CONSUMPTION AND CREDIT

\begin{tabular}{lc}
\hline \hline Country & Correlation \\
\hline \hline Mexico & 0.93 \\
Chile & 0.60 \\
Israel & 0.85 \\
\hline
\end{tabular}

Note: For Israel, credit is unlinked bank credit to the nonfinancial private sector, for Mexico it is private sector. and for Chile it is total claims on the private sector from commercial banks and other banking institutions.

In order to get a better sense of how consumption and credit are related, we present a scatterplot of per capita consumption and per capita credit for each country. Figures 4,5, and 6 show that in all cases consumption and credit are positively related and a regression line of consumption on a constant and credit shows that this relationship fits quite well. 
MEXICO

\section{FIGURE 4}

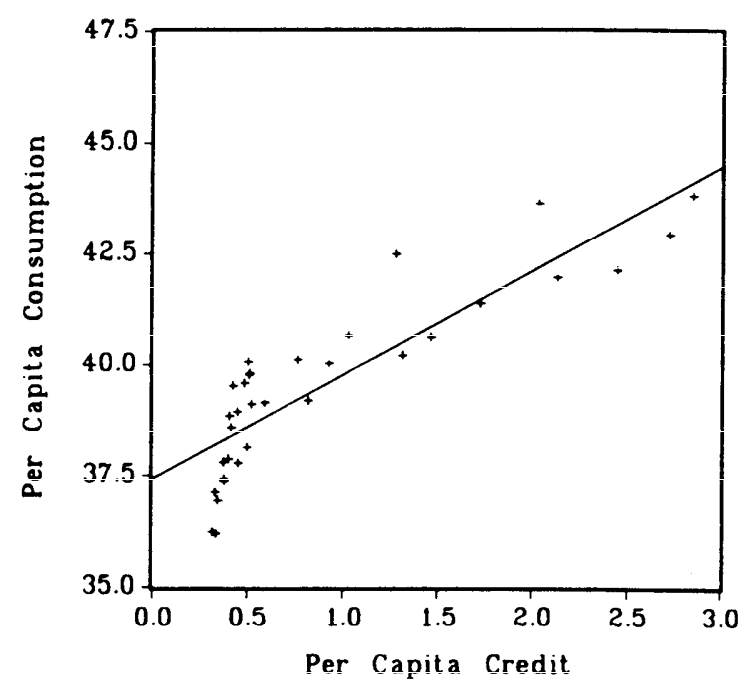

CHILE

\section{FIGURE 6}

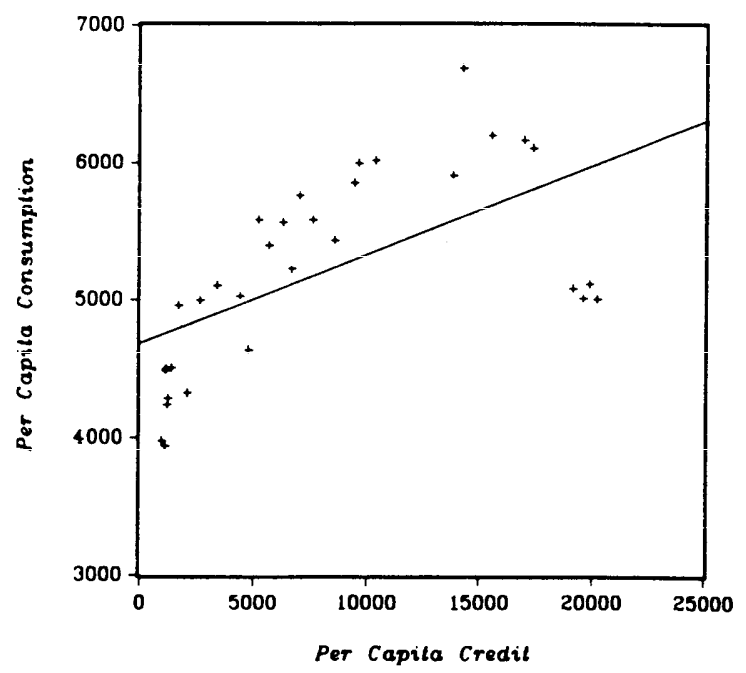

\section{FIGURE 5}

ISRAEL

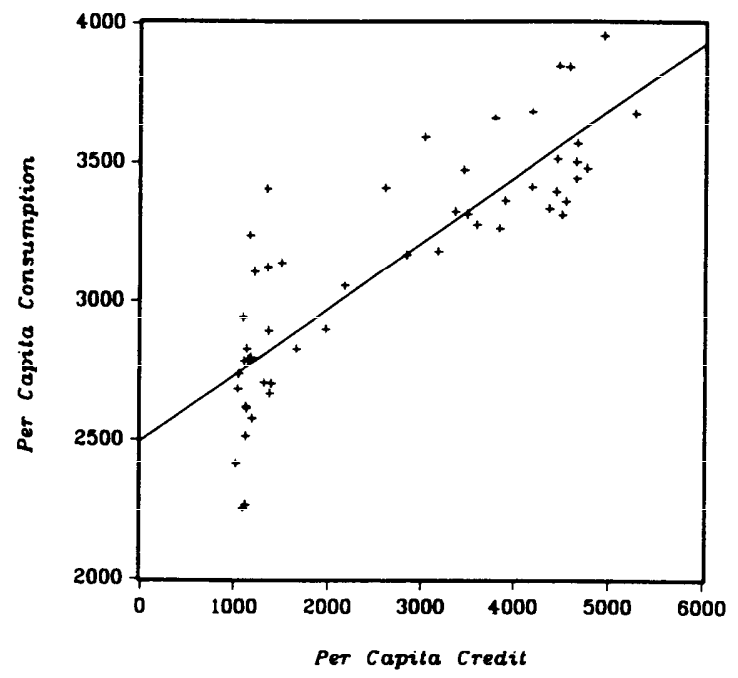


These correlations suggest that credit might be an important determinant of consumption if it works to reduce the share of households that are liquidity constrained in the economy.19/ The reduction in liquidity constraints can generate the consumption booms we observe because it allows consumers who desire to consume more, but could not due to borrowing constraints, to increase their consumption and to reduce their excess savings; or by allowing them to purchase the durables they have been waiting to buy.

\section{IV.3 Sources of Credit Expansions After Stabilizations}

The evidence presented in the previous section, shows that increases in credit after stabilizations play an important role in reducing credit constraints after these plans were enacted. In this section, I look at the exogenous sources of these credit expansions.

There are three possible channels through which credit can increase after a stabilization. These channels are evident when looking at the following accounting identity from a bank balance sheet.

$$
\text { Private Sector Loans }=\text { Deposits }- \text { Reserves }- \text { Govt. Loans }
$$

First, an increase in deposits given the level of public debt held by banks (and the level of reserves) increases the supply of loans to the private sector. The increase in deposits can come from the repatriation of capital held abroad as inflation stabilizes at lower levels and is reflected in the rapid remonetization of the economy as measured by an increase in M2/GDP. The second channel through which credit availability can increase after a stabilization is through a decline in the level of public debt held by banks at any given level of the ratio of

19/ If we assume that credit is exogenous. we can write $\lambda_{1}=\beta-\gamma c r e d$ and plugging this intó equation $(6)$ we get $\Delta C_{1}=j+\beta \Delta Y_{1}-$ $\gamma \Delta Y_{1}^{*} c r e d d_{t}+\theta \hat{r}_{1}+\varepsilon_{1}$. This was estimated for all the three countries, and in each case $\gamma$ was negative and highly significant The estimates were $\gamma_{\text {mexko }}=-1.04, \gamma_{\text {chuli }}=-1.4 \mathrm{E}-05$, and $\gamma_{\text {irrat }}=-9.3 \mathrm{E}-05$, indicating that an increase in credit reduces liquidity constraints. 
M2 to GDP. Resources from the financial sector which were previously being used to finance the government can now be used to finance the private sector. This crowding in effect of a lower level of public debt occurs independently of the increase in the volume of financial intermediation.

Each of these channels in and of themselves, can explain the increase in availability of credit to consumption following a stabilization. This implies that any (or both) of these reasons could be the key to explaining the decline in liquidity constraints that occurs after stabilizations. In effect, the level of credit in the economy is negatively related to the level of public debt held by the banking sector (scaled by GDP), and positively related to the degree of remonetization, measured by M2/GDP. With these effects in mind, we specify the share of the population that is liquidity constrained endogenously.

$$
\lambda_{t}=\beta+\gamma\left(\frac{M 2}{G D P}\right)_{t}+\delta\left(\frac{B}{G D P}\right)_{t}
$$

where M2/GDP is the ratio of M2 to GDP and B/GDP is the ratio of the real stock of internal public debt held by banks to GDP.20/ We expect $\gamma$ to be negative and $\delta$ to be positive. Equation (9) says that as the economy gets remonetized credit increases so liquidity constraints decrease, and that as the level of debt increases the amount of credit decreases so $\lambda$ increases. Substituting equation (9) into (6) we get

$$
\Delta C_{t}=\mu+\beta \Delta Y_{t}+\gamma M 2 Y_{t}+\delta B Y_{t}+\theta r_{t}+\varepsilon_{t}
$$

20/ B is the sum of the IFS lines 52an, 52b,and 52c for Mexico, the sum of 22a-c,42a-cand 42ap for Chile, and it is line 22a for Israel. The results are approximately the same when the budget deficit was used instead of the stock of public debt. 
where $\mathrm{M} 2 \mathrm{Y}_{\mathrm{t}}=\mathrm{M} 2 / \mathrm{GDP} * \Delta \mathrm{Y}_{\mathrm{t}}$ and $\mathrm{BY}=\mathrm{B} / \mathrm{GDP} * \Delta \mathrm{Y}_{\mathrm{t}}$. I estimated equation (14) for Mexico Chile, and Israel. 21/ The results are shown in Table 11. For Mexico and Chile, it is clear that the remonetization of the economy after the stabilization was a key element in the credit expansion (and therefore in the reduction in liquidity constraints) that ensued. As expected, we see that the estimate of $\gamma$ is negative and significant at the $10 \%$ level. On the other hand, this is not the case for Israel. This is not surprising, since as we mentioned before, the financial system of Israel is very different from that of either Mexico or Chile.

Its highly indexed system acts to protect depositors from inflation and devaluation risk; therefore the level of banking resources available to the private sector did not change much from before the stabilization to after it. The steadying of the exchange rate and consequent sharp drop in devaluation expectations, the drop in inflation, and the rise in real interest rates on local currency accounts led to a drastic change in financial asset holdings, notably a shift from PATAM and other resident deposits to short-term sheqel deposits. In Israel, people kept the money at home but they kept it in accounts linked to the dollar, when the stabilization lowered inflation, people switched from dollars to domestic currency but the amount of resources in the banking system did not change much. This is reaffirmed by the evolution of the volume of financial intermediation as measured by M3/GNP shown in Table 7.

21/ The method of estimation is always TSLS with the same set of instruments as before. 
TABLE 11: $\Delta \mathrm{C}_{\mathrm{t}}=\mu+\beta \Delta \mathrm{Y}_{\mathrm{t}}+\gamma \mathrm{M} 2 \mathrm{Y}_{\mathrm{t}}+\delta B \mathrm{Y}_{\mathrm{t}}+\theta \mathrm{r}_{\mathrm{t}}+\varepsilon_{\mathrm{t}}$

\begin{tabular}{cccc}
\hline \hline $\begin{array}{c}\text { TSLS } \\
\text { Estimates. }\end{array}$ & MEXICO & CHILE & ISRAEL \\
\hline \hline$\mu$ & 1983.11992 .4 & 1975.11989 .4 & 1980.11992 .4 \\
\hline$\beta$ & $0.003(1.0)$ & $-0.007(-.34)$ & $0.009(1.40)$ \\
$\gamma$ & $0.61(2.06)^{\mathrm{b}}$ & $2.80(2.49)^{\mathrm{a}}$ & $0.17(.23)$ \\
$\delta$ & $-3.06(-1.73)^{\mathrm{c}}$ & $-2.24(-1.63)^{\mathrm{c}}$ & $-0.92(-.57)$ \\
$\theta$ & $2.33(1.98)^{\mathrm{b}}$ & $0.89(.10)$ & $0.36(1.35)^{\mathrm{d}}$ \\
$\mathrm{N}$ & $0.02(.65)$ & $-0.05(-.64)$ & $-0.008(-.75)$ \\
\hline
\end{tabular}

Note: The sample period for Mexico begins in 1984.1 since data on the public stock of debt are not available earlier. t-statistics are presented in parentheses. (a)indicates significant at the $1 \%$ level, (b) indicates significant at the 5\% level, and (c) at the $10 \%$ level, and (d) at the $15 \%$ level.

Looking at the results for the estimate of $\delta$ we see that it is positive (as expected) in all cases, but it is only significant in Mexico and Israel. This implies that for Mexico the channels through which credit expansions occurred were both a remonetization of the economy and the fall in public debt held by the banking sector.

The crowding in effects from a fall in public debt held by the banking system are also quite important in Israel. This is logical since one of the principal objectives of the stabilization plan was to drastically reduce the deficit to GDP ratio. Even though this was the case in Chile as well, the data for Chile are very bad and some of the missing years were interpolated from the existing series. 22/

In addition to the two channels through which credit expansions can take place already mentioned, there is a third factor. Banks can issue liabilities abroad and use these

22f I tried a non-iinear specification for $\lambda$ in order to ensure that it is always between 0 and 1 since the linear specification has the problem that $\lambda$ can become negative as M2J

GDP gets large. or larger than one as B/GDP gets too large. I specified $\lambda$ as $\lambda=\gamma\left[1 /\right.$ exp $\left.^{\left(M_{2} / G_{D P}\right)}\right]-\delta\left[1 /\right.$ exp $\left.^{(8 / G D P)}\right]$ and estimated $\Delta C_{1}=\mu+\gamma \Delta Y_{1}^{*}\left[1 / \exp ^{(M / G D P}\right]-\delta \Delta Y_{1}^{*}\left[1 / \exp ^{(B / G D P)}\right]+\theta r_{1}+\varepsilon_{1}$. The results are the same for each country. 
resources to increase the amount of loans to the private sector. In order to take this effect into account we respecified $\lambda$ as

$$
\lambda_{t}=\beta+\gamma\left(\frac{M 2}{G D P}\right)_{t}+\delta\left(\frac{B}{G D P}\right)_{t}+\rho\left(\frac{F L}{G D P}\right)
$$

where FL are the real short-term foreign liabilities of the banking sector. Substituting equation (11) into equation (6) we get

$$
\Delta C_{t}=\mu+\beta \Delta Y_{t}+\gamma \dot{M} 2 Y_{,}+\delta B Y_{t}+\rho F L Y_{t}+\theta r_{t}+\varepsilon_{t}
$$

where FLY, $=$ FL/GDP $* \Delta Y_{t}$. We expect $\gamma$ and $\rho$ to be negative and $\delta$ to be positive. The results are presented in Table 12.

TABLE 12: $\quad \Delta \mathrm{C}_{\mathrm{t}}=\mu+\beta \Delta \mathrm{Y}_{\mathrm{t}}+\gamma \mathrm{M} 2 \mathrm{Y}_{\mathrm{t}}+\delta \mathrm{B} \mathrm{Y}_{\mathrm{t}}+\rho \mathrm{FLY} \mathrm{Y}_{\mathrm{t}}+\theta \mathrm{r}_{\mathrm{t}}+\varepsilon_{\mathrm{t}}$

\begin{tabular}{cccc}
\hline \hline TSLS Estimate & MEXICO & CHILE & ISRAEL \\
\hline & 1984.11992 .4 & 1975.11992 .4 & 1981.31992 .4 \\
\hline$\mu$ & $0.004(1.36)$ & $-0.004(-.16)$ & $0.006(.63)$ \\
$\beta$ & $1.26(2.79)^{\mathrm{a}}$ & $2.4(1.78)^{\mathrm{c}}$ & $4.35(1.0)$ \\
$\gamma$ & $-2.02(-1.37)$ & $-3.54(-1.61)^{\mathrm{c}}$ & $-5.24(-.89)$ \\
$\delta$ & $1.57(1.40)^{\mathrm{d}}$ & $2.54(.25)$ & $1.81(1.34)^{\mathrm{d}}$ \\
$\rho$ & $-59.1(-1.78)^{\mathrm{c}}$ & $6.48(.82)$ & $-4.17(-1.24)$ \\
$\theta$ & $0.002(.40)$ & $-0.08(-.82)$ & $0.004(.28)$ \\
$\mathrm{N}$ & 36 & 60 & 46
\end{tabular}

Note: The sample period for Mexico begins in 1984.1 since data on the public stock of debt are not available earlier. t-statistics are presented in parentheses. (a)indicates significant at the $1 \%$ level, (b) indicates significant at the 5\% level, and (c) at the $10 \%$ level, and (d) at the $15 \%$ level.

The results show that only for Mexico does the increase in foreign liabilities by the banking sector make a difference in the increase in credit and consumption. It also makes the remonetization not as important ( $\gamma$ is significant at the $20 \%$ level). For Chile and Israel this 
channel does not seem to matter and as before the relevant channels are the remonetization and the fall in the public debt held by banks respectively.

\section{CONCLUSIONS}

In looking at the role of credit in the post-stabilization consumption booms of Mexico, Chile, and Israel, we find that the expansions in banking credit after the stabilizations are indeed an important determinant of consumption. The paper shows that there is strong evidence against the PIH and that liquidity constraints were quite important in these countries prior to the stabilization. In addition, we see that the share of households that are liquidity constrained falls sharply after the stabilizations. This effect is strongest in the case of Mexico. The decline in liquidity constraints can generate a decline in excess savings and/or a lumping of expenditures on consumer durables which can help explain the consumption booms that we observe.

In looking at the sources of credit to consumers in these economies, I find that for the case of Mexico, all three of the sources examined played an important role. Credit to consumers expanded through the remonetization of the economy, through the decrease in the ratio of debt held by banks to GDP, and through the increase in foreign borrowing by banks. For Chile, I find that only the remonetization matters; and for Israel only the crowding in effect matters. These results highlight the difference in the financial markets of Mexico and Chile on the one hand, and Israel on the other. Israel's highly indexed and developed financial system mean that there was not a significant increase in the volume of financial intermediation after the stabilization since it was already fairly high. Consumers in Israel had access to domestic indexed credit prior to the stabilization whereas in Mexico and Chile this was not the case. This means that the impact of the increase in credit in Mexico and Chile is 
much larger than in Israel. These results suggest that the role of the financial system in the economy is quite important when monitoring the progress of an economy after a stabilization.

A country considering an exchange rate based stabilization should be very vigilant of developments in the financial sector. More importantly, to avoid a boom-and-bust cycle and the possibility of banking crises, countries should keep their financial systems tightly monitored and regulated, particularly during the expansionary phase. 


\section{REFERENCES}

Aspe,A.P. 1993. Economic Transformation: The Mexican Way. M.I.T. Press

Banco de Mexico. 1990,1992,. Informe Anual.

Banco de Mexico 1991, 1993. The Mexican Econmy. Annual Report of the Bank of Mexico

Bank of Israel. 1985-1992. Annual Report.

Barsky,R.B. Three Interest Rate Paradoxes. MIT Ph.D. Dissertation. 1985.

Bayoumi,T.,and P.Koujianou. 1989. The Effects of Financial Deregulation on Consumption. IMF Working Paper 89/88,October.

Bruno,M and Meridor,L.R. 1991. The Costly Transition from Stabilization to Sustainable Growth: Israel's Case. in Bruno et. al.. eds. Lessons of Economic Stabilization and Its Aftermath. The MIT Press.

Calvo.G.A. 1986. Temporary Stabilization: Predetermined Exchange Rates. Journal of Political Economy, 94 (December):383-398

Calvo,G.A. 1988. Costly Trade Liberalizations: Durable Goods and Capital Mobility. IMF Staff Papers, 35:461-473

Campbell,J.Y. and Mankiw,N.G. 1989. Consumption, Income, and Interest Rates: Reinterpreting the Time Series Evidence. NBER Macroeconomics Annual 1989.

Campbell.J.Y. and Deaton,A. 1989. Why is Consumption So Smooth? Review of Economic Studies 1989. 56

Christiano.l. 1987. Is Consumption Insufficiently Sensitive to Innovations in Income?. American Economic Review (Papers and Proceedings), 77 337-341.

Deaton,A. 1989. Savings and Liquidity Constraints. Princeton University

De Long, J.B., and L.H. Summers 1987. The Changing Cyclical Variability of Economic Activity in the

United States. in NBER Dornbusch, R. 1986. External Debt, Budget Deficits, and Disequilibrium Exchange Rates. in Smith, G. and J. Cuddington ed. International Debt and the Developing Countries. The World Bank.

Edwards,S.and A.Cox-Edwards. 1991. Monetarism and Liberalization: The Chilean Experience. University of Chicago Press.

Flavin.M. 1981. The Adjustment of Consumption to Changing Expectations About Future Income. Journal of Political Economy,89: 974-1009. 
Giavazzi,F., and M.Pagano. 1990. Can Severe Fiscal Contractions be Expansionary?. NBER Macroeconomics Annual 1990 (5):75-122.

Hall,R.E.1978. Stochastic Implications of the Life-Cycle Permanent Income Hypothesis. Journal of Political Economy 86 (6):971-87

Hall, R.E. 1988, Intertemporal Substitution in Consumption. Journal of Political Economy 96 339-357.

Hansen,L.P. and K. J. Singleton 1982. Generalized Instrumental Variables Estimation of Nonlinear

Rational Expectations Models. Econometrica 50, 1269-86.

Hayashi,F. 1982. The Permanent Income Hypothesis: Estimation and Testing by Instrumental Variables. Journal of Political Economy 90 (5):895-916

Jappelli,T.,and M.Pagano.1989. Consumption and Capital Market Imperfections: An International Comparison. American Economic Review 79 (5):1088-1105.

Kiguel, M. and N. Liviatan 1992. The Business Cycle Associated with Exchange Rate Based Stabilization, The World Bank Economic Review 6.279-305

Mankiw, G. 1981.

Rossi, N. 1988. Government Spending,The Real Interest Rate, and the Behaviour of LiquidityConstrained Consumers in Developing Countries, IMF Staff Papers. 85, 104-40.

Sachs, J. 1985. The Dollar and the Policy Mix:1985. Brookings Papers on Economic Activity. 1. 117-97.

Sargent, T.J., 1982. The End of Four Big Inflations. in Robert E. Hall,ed. Inflation: Causes and Effects. Chicago: University of Chicago Press. 41-95.

Wooldridge,J.M. 1990. A Note on the LM and the F-test for Two Stage Least Squares Regressions. Economics Letters (34) 151-155.

Working,H. 1960. Note on the Correlation of First Differences of Averages in a Random Chain. Econometrica 28:916-18

West,K.D. 1988. The Insensitivity of Consumption to News about Income. Journal of Monetary Economics. 21: 17-23. 


\section{International Finance Discussion Papers}

IFDP

Number

568

567

566

565

564

563

562

561

560

559

558 $\underline{\text { Titles }}$

Author(s)

$\underline{1996}$

The Role of Credit in Post-Stabilization Consumption Booms

Hazards in Implementing a Monetary Conditions Index

Financial Innovation And The Speed of Adjustment of Money Demand: Evidence From Bolivia, Israel, And Venezuela

Long-Term Evidence on the Tobin and Fisher Effects: A New Approach

Some Evidence on the Efficacy of the UK Inflation

Targeting Regime: An Out-of-Sample Forecast Approach

The Use of the Parallel Market Rate as a Guide to Setting the Official Exchange Rate

Country Fund Discounts and the Mexican Crisis of December 1994: Did Local Residents Turn Pessimistic Before International Investors?

Eastern European Export Performance during the Transition

Inflation-Adjusted Potential Output

The Management of Financial Risks at German Nonfinancial Firms: The Case of Metallgesellschaft

Broad Money Demand and Financial Liberalization in Greece

Stockholding Behavior of U.S. Households: Evidence from the 1983-89 Survey of Consumer Finances
Martina Copelman

Kari H. Eika

Neil R. Ericsson

Ragnar Nymoen

Martina Copelman

Shaghil Ahmed

John H. Rogers

Chan Huh

Nita Ghei

Steven B. Kamin

Jeffrey A. Frankel

Sergio L. Schmukler

Nathan Sheets

Simona Boata

Jane T. Haltmaier

Allen B. Frankel

David E. Palmer

Neil R. Ericsson

Sunil Sharma

Carol C. Bertaut

Please address requests for copies to Intemational Finance Discussion Papers, Division of International Finance, Stop 24, Board of Governors of the Federal Reserve System, Washington, DC 20551. Email: graym@frb.gov. Fax: (202)736-5638. 


\section{International Finance Discussion Papers .}

IFDP

Number

557

556

555

554

553

552

551

550

549

548

547

546

545 $\underline{\text { Titles }}$

1996

Firm Size and the Impact of Profit-Margin Uncertainty on Investment: Do Financing Constraints Play a Role?

Regulation and the Cost of Capital in Japan: A Case Study

The Sovereignty Option: The Quebec Referendum and Market Views on the Canadian Dollar

Real Exchange Rates and Inflation in Exchange-Rate

Based Stabilizations: An Empirical Examination

Macroeconomic State Variables as Determinants

of Asset Price Covariances

The Tequila Effect: Theory and Evidence from Argentina

The Accumulation of Human Capital: Alternative Methods and Why They Matter

Alternatives in Human Capital Accumulation: Implications for Economic Growth

More Evidence on the Link between Bank

Health and Investment in Japan

The Syndrome of Exchange-Rate-Based

Stabilization and the Ũncertain Duration of

Currency Pegs

German Unification: What Have We Learned

from Multi-Country Models?

Returns to Scale in U.S. Production: Estimates and Implications

Mexico's Balance-of-Payments Crisis: A Chronicle of Death Foretold
Author(s)

Vivek Ghosal

Prakash Loungani

John Ammer

Michael S. Gibson

Michael P. Leahy

Charles P. Thomas

Steven B. Kamin

John Ammer

Martín Uribe

Murat F. Iyigun

Ann L. Owen

Murat F. Iyigun

Ann L. Owen

Michael S. Gibson

Enrique G. Mendoza

Martin Uribe

Joseph E. Gagnon

Paul R. Masson

Warwick J. McKibbin

Susanto Basu

John G. Fernald

Guillermo A. Calvo

Enrique G. Mendoza 


\section{International Finance Discussion Papers}

IFDP

Number

$\underline{\text { Titles }}$

Author(s)

$\underline{1996}$

544 The Twin Crises: The Causes of Banking and

Graciela L. Kaminsky

Balance-of-Payments Problems

Carmen M. Reinhart

$543 \quad$ High Real Interest Rates in the Aftermath of

Disinflation: Is it a Lack of Credibility?

Graciela L. Kaminsky

Leonardo Leiderman

542 Precautionary Portfolio Behavior from a Life-Cycle

Perspective

Carol C. Bertaut

Michael Haliassos

541 Using Options Prices to Infer PDF's for Asset Prices:

William R. Melick

An Application to Oil Prices During the Gulf Crisis

Charles P. Thomas

540 Monetary Policy in the End-Game to Exchange-Rate

Based Stabilizations: The Case of Mexico

Steven B. Kamin

John H. Rogers

539 Comparing the Welfare Costs and the Initial Dynamics

of Alternative Temporary Stabilization Policies

Martin Uribe

538 Long Memory in Inflation Expectations: Evidence

from International Financial Markets

Joseph E. Gagnon

537 Using Measures of Expectations to Identify the Effects of a Monetary Policy Shock

Allan D. Brunner

536 Regime Switching in the Dynamic Relationship between the Federal Funds Rate and Innovations in Nonborrowed Reserves

535 The Risks and Implications of External Financial

Shocks: Lessons from Mexico

Edwin M. Truman

534 Currency Crashes in Emerging Markets: An Empirical Treatment

Jeffrey A. Frankel

Andrew K. Rose

533 Regional Patterns in the Law of One Price: The Roles of Geography V's. Currencies

Charles Engel

John H. Rogers 